\title{
Literature Study on The Influence of Mathematics Basic Skills to Work Out Physics Problems
}

\author{
Murni $^{1}$, Rina Mirdayanti ${ }^{2}$, Burhanuddin $\mathrm{AG}^{3}$ \\ ${ }^{1}$ Mathematics Education, University of Abulyatama, Indonesia \\ ${ }^{2}$ Physics Education, University of Abulyatama, Indonesia \\ ${ }^{3}$ Mathematics Education, University of Serambi Mekkah, Indonesia \\ 1'murni fkip@abulyatama.ac.id, ${ }^{2}$ rinamirdayanti@abulyatama.ac.id, ${ }^{3}$ burhanuddinag@gmail.com
}

\begin{abstract}
Keywords:

Relationship,

Mathematical,

Physics Concepts.

This research aims to describe the correlation of mathematics skills as the basic skills that students need in order to solve physics problems that seem complicated and difficult to understand. Physics describes the order of nature in mathematical equations thus the ultimate goal of physics in finding other sequences and making use of it in real life can be achieved more easily. This research was conducted using literature study approach. The data were collected by means of documentation with secondary data obtained from several references. The data were then analyzed using content analysis technique. A relevant summary of the correlation between proper mathematical understanding and complex physics problem-solving ability was attained from this research. These results were confirmed by the data gained from a range of references in the form of books, both online and offline journals as well as prior conferences that have been read, reviewed and analyzed by focusing on the mastery of mathematics skills in developing students' critical thinking to work out physics problems.
\end{abstract}

Article History:

Received: 29-06-2018

Revised : 20-08-2018

Accepted: 29-08-2018

Online : 30-08-2018

\author{
This is an open access article under the CC-BY-SA license \\ crossret \\ https://doi.org/10.31764/ijeca.vli2.2146
}

\section{A. INTRODUCTION}

Physics is a subject that is considered as tricky by some students in different educational level, both at the first level and at the upper level including the college level. Physics in general is the study of the order of the universe and it tries to, as much as possible, utilize this order for two things; find other orders in the universe and exploit the orders that have been found to benefit human lives (Nathanael, 2011).

Mundilarto (mundilarto, 2002) argues that Physics consists of many concepts and principles that are generally very abstract. The challenges faced by most students are in interpreting the various physics concepts and principles because it is essential for them to be able to decipher these concepts and principles accurately leaving no vague or ambiguous ideas. Students' ability to identify and deduce the concepts of physics is clearly a vital prerequisite skill for them in order to be able to extrapolate concepts and make sophisticated inferences or to work out physics problems by using said concepts. 
In another study, Smigiel \& Sonntag (Smigiel \& Sonntag, 2013) consider the same problem in France' physics education. According to them, most teachers concentrate only on mathematical calculations rather than on actual scientific concepts hence students cannot understand the meaning behind the formula (Kabil, 2015). Understanding the concept of physics is not an easy feat to accomplish unless accompanied by the mastery of basic mathematical skills, so that it can be said physics is an applied mathematics model that mutually reinforce one another. Mathematics as a subject serves to develop the ability to communicate by using numbers and symbols and nimble mind that can explicate and help solve problems in everyday life (Adiromanita, 2008). Mathematics is a universal science underlying the development of modern technology with important roles in various disciplines and advances the power of human minds (Purbaningrum, 2017).

Mathematics proficiency has an important role in everyday life especially in honing and training someone to think rationally and logically. Without realizing it, mathematics influences and provides solutions to many problems in technology development and science. One of the examples is the case in physics pertaining to the acceleration of natural order in which translates into velocity and acceleration. This sentence explains the concept of acceleration on moving objects. Explanation on this concept will be challenging unless it utilizes mathematical equation where symbols are used to help to interpret the concept; acceleration is denoted by a, change of velocity by $d v$, and acceleration by $d t$. Acceleration concept formulated in mathematical equation becomes $\mathrm{a}=\mathrm{dv} / \mathrm{dt}$. Hence, it can be concluded that natural order expressed in equation will become simpler and beneficial as a foundation to understand other phenomena (Nathanael, 2011) or in other words, students will be able to understand the concepts of physics if they have already skillfully master math basics as the groundwork. Therefore, the concept of nature cannot be fully expressed and put in to good use without a mathematical approach.

An equation may appear very simple such as the following $y=m x+b$.

In brief, this equation suggests a simple calculation, which determines the value of " $y$ " in terms of "m" and " $x$ " and "b". Mathematics oftentimes deliberately adopts a minimalist look like this. What we know about math is that it is unwaveringly precise and accurate (on account of axioms), and only that specific knowledge will be used as a base to form a new one. Equations, in a nutshell, understood in the realm of conventions, straight lines, and graphics are much broader than the narrow definition of the "y" as a mere symbol.

The application of mathematics to problems in physics will physically increase the comprehension to interpret mathematical functions, e.g. the following example in physics equation $\mathrm{v}=\mathrm{v} 0+\mathrm{at}$. $\mathrm{v}$ is the velocity of an object, $\mathrm{v} 0$ is the initial velocity, and a is the constant acceleration of the object, and $t$ is time. This equation is mathematically identical to equation 1 and can be seen as a representation of a linear relationship graph (Redish \& Kuo, 2015). They emphasize that mathematics is a combination of calculations and concepts. At a conceptual level, mathematics is structured to be independent of time and multiplicity (Kauffman \& Ul-Haq, 2015) .

A research conducted by Ervina Rhahim, Edy Tandililing, and Syukran Mursyid establish a positive correlation between performance in physics and prior mathematics knowledge. Their findings reveal that there are students with excellent math skills but low physics performance. However, they disclose that this was due to students' misconceptions that lead to physics and mathematics errors, with 75\% and 65\% errors respectively (Ervina Rhahim, Edy Tandililing, 2015). 
The correlation between physics and mathematics has been proven true. Mathematical techniques are useful tools to solve problems of physics, because in reality physics cannot be separated from mathematical calculations such as addition, subtraction, multiplication, differentials, integrations and other. Haryadi states that in order to solve physics problems using differentials and integrations, mathematical skills are required to improve the kinematic concepts comprehension (Haryadi, 2016). Quale (Quale, 2011) states that mathematical formulation is very much needed to represent the scientific laws used and to investigate the consequences of physics laws and other various branches of disciplines which indicate that the relationship between mathematics and physics is unseparable. Consequently, prior mathematics mastery is concluded as vital to enhance performance in physics.

The correlation between mathematics and physics has been widely reported through several studies. According to Tzanakis (Constantitos Tzanakis, 2002) mathematics and physics have a close relationship in which mathematical methods are applied in physics and its concepts, and vice versa, physical opinions and ways of thinking are applied in mathematics as well. The ability to create a strategy can be interpreted as the ability to plan for problem solving. Students have to find a way or strategy that could be taken advantage of to solve a problem.

Physics and math have a close relationship, namely (1) the mathematical methods used in physics and (2) physical concepts, opinions, and ways of thinking are used in mathematics. Thus the relationship between physics and mathematics should not be ignored in the discipline. Wikipedia also writes that physics is also closely related to mathematics. Furthermore, many physics theories are expressed in mathematical notations.

Physics requires a relatively high intellect demonstration from the students. Strategic thinking skills is necessary in studying physics, in addition to numeracy, manipulation and observation skills, as well as the ability to respond to a problem critically (Muldilarto, 2002). The capacity to strategize can be interpreted as the ability to plan for problem solving. Students have to find a way or strategy that could be used to solve a problem. The ability to make algorithms indicates the importance on the completion or workmanship on the problems. Students should be able to make use of appropriate mathematical skills to make conclusions (Ani Rusilowati, 2006).

Students are not only learning about concepts or formulas in physics, but also learning on how to use them to delve further to investigate physics phenomena and problems. In order to understand physics well it is necessary to employ various formulas according to the process and procedure to solve physics problems (Irianti, 2008).

Physics is directly connected to mathematics where every problem in physics can be solved by mathematical means. Wardoyo, et al. argue that in physics, mathematics plays a major role, in addition to its ability to solve physics problems from the simplest to the most complex forms, mathematics greatly helps one's reasoning in tracing the intricate twists and turns of physics (Wanhar, 2008).

Based on the study conducted by Baharuddin, he obtained that logical reasoning ability is needed in solving physics problems. Similarly, Utari claims that students did not have optimum achievement due to the lack of ability to reason logically because comprehension and logical thinking greatly affect mathematical and physical concepts realization. On that account, students' ability and comprehension of mathematical concepts is needed to positively support the teaching of physics (Wanhar, 2008).

Physics is a branch of science concerned with natural phenomena, including the materials, motion, and energy. In other words, physics is a science of the world around us and how 
everything in it works (Lang, 2000). Physics evolves through experimental observation and quantitative measurement with the ultimate goal of discovering the basic laws of nature. Furthermore, these basic laws were used in the development of theory to predict the results of subsequent experiments. The basic laws in theoretical physics are expressed in the language of mathematics. This notion implies that mathematics plays a very important role in describing and explaining macroscopic and microscopic physical phenomena. Mathematical representation in the concepts of physics can help students to learn physics (Halliday et al., 2004).

Diverse mathematical concepts are used to solve problems in physics, one of them is trigonometry. Trigonometry is widely used in mechanics so it can be said only those who have the ability in trigonometry can solve mechanical problems. A student who masters a certain concept in trigonometry can transfer such ability in other situations, such as physics. This is called the transfer of learning (Hasbi, 2012).

The relationship between mathematics and physics has been widely reported in varying fieldworks. Meltzer in Hasbi (Hasbi, 2012) suggests that many researchers have found a positive correlation between physics performance and mathematical skills in college level based on the pretest he conducted. The pretest normally contains algebra and trigonometry problems although most researchers do not reveal their test samples.

Rahmah in her study concludes that physics achievement is influenced by mathematics skills and motivation to learn (Hasbi, 2012). Meanwhile, a research conducted by Suharto discovers that students' math ability or mastery strongly reinforce students' physics mastery (Linuwih, 2013).

Based on the analysis of several preceding studies that have been carried out to find out the relationship between application of mathematics in the comprehension of physical concepts, this study aims to describe the relationship between mathematical ability as the basic skills that students need in solving physics problems in general.

\section{B. METHODS}

This study employs literature study or library research approach. Literature study is a type of research that collects information and data with a wide range, both online and offline, references such as journals, books, proceedings, and so on. The data sources in this study are journals, proceedings, and scientific articles related to the selected topic consisted of 1 book, 2 proceedings, and 18 germane journals.

The data in this research were collected through documentation by looking for data about things or variables in the form of some references relevant to this research, whether it was in the form of articles, journals, proceedings, books and so forth.

After that the data were analyzed using content analysis method. The data went through the process of selecting, comparing, combining and sorting the various ideas until the most appropriate one was found. From the standpoint of a content analysis study, document scanning is considered as the most appropriate method for this research. As stated by Bauer (Bauer, 2003), content analysis is commonly used in qualitative research as an analytical method that organizes some features of numerically written text (Hüseyin Uzunboylua, 2014). 


\section{RESULT AND DISCUSSION}

As a content analysis study, it aims to examine the influence of basic mathematical skills in solving physics problems. With this specific purpose in mind, this study adapted several journal references and proceedings by previous researchers. Research findings that reinforce the relationship between mathematical skills and the ability to solve physics problems.

A preceding study conducted by Rhahim, Ervina, et al., establishes that there is a significant relationship between math skills and the ability to solve physics problems with a significant correlation coefficient of 0.9041 which consequently remarkably affect the ability to solve problems as well. Based on Rhahim et al.'s research, two groups of data were identified. The first one was the relationship between math skills and the ability to solve physics problems and the second is the number of students with misconceptions. Rhahim et al. reported that the higher the students' math skills, the greater the students' ability in solving physics problems. Conversely, if the students' math skills are low then so is the students' ability to solve the physics problems. Therefore, mathematical skills are one of the factors that cause low physics learning achievement. This is in accordance with the statement proposed by Tzanakis (Constantitos Tzanakis, 2002) that mathematics has a close relationship with physics. These findings also fit into Anisa (2011) and Lukyto (2009) studies that expose mathematics involvement in solving physics problems (Ervina Rhahim, Edy Tandililing, 2015).

The research conducted by Kereh, C.T., et al. with the objectives to find out about: (1) basic mathematical contents that are directly related to nuclear physics introduction (NPI) materials, and (2) the correlation between students' mastery on basic mathematics and their mastery on NPI in a lecture. This study was conducted in a quasi-experiment design on two groups consisted of 28 people in each group. The first group was taught using conventional lectures with eight face-to-face meetings in the classroom while the second group was taught using blended learning instruction. The two groups performed both initial and final tests on basic mathematics and NPI. The results of this study indicated that there was a high correlation between the mastery of basic mathematics and NPI. The literature review found that NPI, that covered topics such as Nuclear Structure, Radioactivity, Nuclear Reactions, and Decay, employs certain basic mathematics concepts namely integers, fractions, exponential numbers, exponential functions, logarithms, tables, and graphs. The exclusion of calculus in this case is due to the fact that NPI operates on basic algebra only. The materials mentioned above are all accommodated in the prepared test instruments (Kereh, lilisari, P. C. Tjiang, 2014).

The research carried out by Ika Fitri Rahayu, Mitri Irianti and Zulirfan found the significant influence of basic math skills and study habits on physics learning outcomes. Individually the basic math skills notably affected physics learning outcomes. This is in accordance with Lukyto's (Lukyto, 2009) study where he revealed that there was a noteworthy correlation of basic mathematics skills on students' physics learning outcomes in the chapter of study of light with a contribution factor of $9.54 \%$. Rahayu, et al. (Rahayu, 2014) summarized that basic math skills and learning habits are two factors that affect a person's learning outcomes. Basic math skills are the basic abilities possessed by someone in order to perform calculations whereas learning habits are external factors retained due to repeated routines. In consequence, to improve physics learning outcomes, especially in solving physics problems, students can develop their basic math skills by studying mathematics concepts and have a lot of practices in solving basic math problems.

David E. Meltzer in his research added that there are a lot of investigations into the factors that underlie the variations in each student's physics performance in college. Numerous studies 
have reported a positive correlation between students' math skills and their physics exam scores at the college level. He said the results of his investigation on several factors, including mathematical ability, may be related to variations in students' ability to achieve conceptual learning in physics exercises using interactive engagement methods. He reported that the normalized students' learning outcomes were not significantly correlated with pretest scores on physics concepts tests. In contrast, three out of the four population samples were found to prove a significant relationship between normalized learning acquisition and students' scores and math skills. Both male and female samples independently showed a correlation between learning acquisition and math skills.

Paul Adrien Maurice Dirac in his lecture presented at the JAMES SCOTT prize lectureship on 6 February 1939 on the relationship between mathematics and physics acknowledged in his study of natural phenomena in which he unveiled that nature has two methods to develop. (1) experimental and observational methods, and (2) mathematical reasoning methods. Dirac argued that the generally accepted scheme of physics in the last century was a mechanistic scheme as a starting point. He considered the entire universe to be a dynamic system (of course a very complicated dynamic system), subject to the laws of motion that are essentially of the Newtonian type. The role of mathematics in this scheme is to represent the laws of motion with equations, and to obtain solutions of equations referring to observed conditions (P. A. M. Dirac, 1939). Here, no doubt, mathematics was perceived as having a legitimate role in representing the particulars of physics. Mathematics can be a formula with a practical concept in answering a physics analysis.

\section{CONCLUSION AND SUGGESTIONS}

Based on the research findings and discussion above, it can be concluded that: this study shows the correlation between mathematics skills and physics problem solving where both elements mutually and significantly correspond with one another. This finding is also backed up by several references such as journals and proceeding studies.

It is suggested that other researchers interested in this issue to conduct a more in-depth research to compare which appropriate strategies that can be used to refine both students' physics concepts comprehension and logical thinking skills to improve students' critical thinking process.

\section{REFERENCES}

Adiromanita, H. (2008). Pola belajar siswa dalam menyelesaikan soal cerita matematika disekolah dasar kelas IV [Universitas Muhammadiyah Surakarta]. http://eprints.ums.ac.id/1927/

Ani Rusilowati. (2006). Profil Kesulitan Belajar Fisika Pokok Bahasan Kelistrikan Siswa SMA di Kota $\begin{array}{lllll}\text { Semarang. Jurnal Pendiidkan } & \text { Indonesia, }\end{array}$ https://journal.unnes.ac.id/nju/index.php/JPFI/article/view/163

Bauer, J. (2003). 2003 earnings survey. The outlook is bright. $R N, 66(10), 54-60$.

Constantitos Tzanakis. (2002). On The Relation Between Mathematics And Physics In Undergraduate Teaching. Semantic Scholar.

Ervina Rhahim, Edy Tandililing, S. (2015). Hubungan Keterampilan Matematika Dengan Kemampuan Menyelesaikan Soal Fisika Terhadap Miskonsepsi Siswa Pada Impuls Momentum. Jurnal Pendidikan Dan Pembelajaran Khatulistiwa, 4(9).

Halliday, D., Resnick, R., \& Walker, J. (2004). Fundamentals Of Physics (7Th Ed). In John Wiley \& Sons.

Haryadi, R. (2016). Korelasi Antara Matematika Dasar Dengan Fisika Dasar. Jurnal Penelitian Dan Pembelajaran Matematika, 9(1), 124-127. https://doi.org/10.30870/JPPM.V9I1.988.G789

Hasbi, M. (2012). Pengaruh Kemampuan Trigonometri Terhadap Kemampuan Fisika Dikaitkan dengan 
Gaya Kognitif Mahasiswa Program Studi Pendidikan Fisika FKIP Universitas Tadulako. Jurnal Aksioma, 1(1), 63-72.

Hüseyin Uzunboylua, G. A. (2014). Research in Physics Education: A Study of Content Analysis. Procedia Social and Behavioral Sciences, 425-437.

Irianti, M. (2008). Peningkatan Kemampuan Pemecahan Masalah Dan Tingkat Penguasaan Mahasiswa Dengan Menggunakan Prosedur Heuristik Pada Pembelajaran Fisika Dasar 1. Sosiohumaniora, 1(3), 45-56. https://doi.org/https://doi.org/10.24198/sosiohumaniora.v10i3.5403

Kabil, O. (2015). Philosophy in Physics Education. Procedia - Social and Behavioral Sciences, 197, 675-679. https://doi.org/10.1016/j.sbspro.2015.07.057

Kauffman, L. H., \& Ul-Haq, R. (2015). The mysterious connection between mathematics and physics. In Progress in Biophysics and Molecular Biology (Vol. 119, Issue 3, pp. 453-459). https://doi.org/10.1016/j.pbiomolbio.2015.08.012

Kereh, lilisari, P. C. Tjiang, J. (2014). Korelasi Penguasaan Materi Matematika Dasar Dengan Penguasaan Materi Pendahuluan Fisika Inti. Jurnal Pendidikan Fisika Indonesia, 10(2), 140-149. https://doi.org/10.15294/jpfi.v10i2.3449

Lang, H. S. (2000). Aristotle Physics Book VIII. Ancient Philosophy, 20(1), 224-228. https://doi.org/10.5840/ancientphil200020125

Linuwih, S. (2013). Konsepsi Alternatif Mahasiswa Calon Guru Fisika Tentang Gaya-Gaya Yang Bekerja Pada Balok. Jurnal Pengajaran Matematika Dan Ilmu Pengetahuan Alam, 18(1), 69. https://doi.org/10.18269/jpmipa.v18i1.259

Lukyto, T. (2009). Hubungan Antara Kemampuan Dasar Matematika dan Kebiasaan Belajar Dengan Prestasi Belajar Fisika Siswa SMP Negeri 3 Ponorogo [Universitas Negeri Malang]. http://fisika.fmipa.um.ac.id/index.php/2011/03/20/hubungan-antara-kemampuan-dasarmatematika-dan-kebiasaan-belajar-dengan-prestasi-belajar-fisika-siswa-smp-negeri-3-ponorogo/

Muldilarto. (2002). Kapita Selekta Pendidikan Fisika. Universitas Negeri Yogyakarta.

mundilarto. (2002). kapita selekta pendidikan fisika. FMIP Universitas Negeri Yogyakarta.

Nathanael, M. (2011). Hubungan Fisika dan Matematika. Http://gurufisikamuda.blogspot.com/. http://gurufisikamuda.blogspot.com/2011/02/hubungan-fisika-dan-matematika.html

P. A. M. Dirac. (1939). The Relation between Mathematics and Physics. Proceedings of the Royal Society of Edinburgh, 122-129. https://doi.org/10.1017/S0370164600012207

Purbaningrum, K. A. (2017). Kemampuan Berpikir Tingkat Tinggi Siswa Smp Dalam Pemecahan Masalah Matematika Ditinjau Dari Gaya Belajar. Jurnal Penelitian Dan Pembelajaran Matematika, 10(2). https://doi.org/10.30870/jppm.v10i2.2029

Quale, A. (2011). On the Role of Mathematics in Physics. Science and Education, 20(3), 359-372. https://doi.org/10.1007/s11191-010-9278-3

Rahayu, I. F. (2014). pengaruh kemampuan dasar matematika dan kebiasaan belajar terhadap hasil belajar fisika siswa kelas xi ipa sman 11 pekanbaru. Program Studi Pendidikan Fisika Universitas Riau.

Redish, E. F., \& Kuo, E. (2015). Language of Physics, Language of Math: Disciplinary Culture and Dynamic Epistemology. Science and Education, 24(5-6), 561-590. https://doi.org/10.1007/s11191-0159749-7

Smigiel, E., \& Sonntag, M. (2013). A paradox in physics education in France. Physics Education, 48(4), 497505. https://doi.org/10.1088/0031-9120/48/4/497

Wanhar. (2008). Hubungan Antara Pemahaman Konsep Matematika Dengan Kemampuan Menyelesaikan Persoalan Matematika. Jurnal Barug, 1(3). 